\title{
Celtic censure: representing Wales in eighteenth-century Germany
}

Article

Accepted Version

Martin, A. E. (2014) Celtic censure: representing Wales in eighteenth-century Germany. Studies in Travel Writing, 18 (2). pp. 122-133. ISSN 1755-7550 doi:

https://doi.org/10.1080/13645145.2014.895261 Available at https://centaur.reading.ac.uk/36598/

It is advisable to refer to the publisher's version if you intend to cite from the work. See Guidance on citing.

To link to this article DOI: http://dx.doi.org/10.1080/13645145.2014.895261

Publisher: Taylor and Francis

All outputs in CentAUR are protected by Intellectual Property Rights law, including copyright law. Copyright and IPR is retained by the creators or other copyright holders. Terms and conditions for use of this material are defined in the End User Agreement.

\section{www.reading.ac.uk/centaur}

\section{CentAUR}

Central Archive at the University of Reading

Reading's research outputs online 


\section{Celtic Censure: Representing Wales in Eighteenth-Century Germany}

In 1800, the young clergyman and naturalist William Bingley published his Tour of North Wales, a work heralded by a critic in the Monthly Review as 'the best Vade Mecum that has yet appeared' on that region of the British Isles. ${ }^{1}$ The landscape, people and culture of Wales had swiftly become the focus of numerous travel accounts by the end of the eighteenth century as British travellers were increasingly compelled to seek pleasure in domestic tourism following the outbreak of the French Revolution, which had rendered Continental travel both difficult and dangerous. Cast by Daniel Defoe in 1732 as a 'monstrous' and 'barren' place 'full of horrid Rocks and Precipices', the Welsh landscape had failed to satisfy early eighteenth-century landscape desires centring upon progress, practicality and prosperity. ${ }^{2}$ But in the 1770s, Wales suddenly seized the British imagination. Romantic travellers, heady with the misty melancholy of Ossian and the lyrical raptures of celtophiles like Thomas Gray and William Mason, sought a proximity to nature that the hoary mountains and gloomy caverns of Wales readily supplied. In 1776 the Gentleman's Magazine, a leading monthly of the day, devoted a whole issue to Welsh castles, heraldry and antiquities, and mentioned Wales at some point or other in every edition throughout the 1780s and 1790s. ${ }^{3}$ This growing predilection for Welsh tours therefore located Bingley's account within an already substantial corpus of writing by English travellers on Wales that included Samuel Jackson Pratt's Gleanings through Wales, Holland and Westphalia (1795), Arthur Aikin's Journal of a Tour through North Wales and a Part of Shropshire (1797), the Reverend Richard Warner's Walk through Wales (1798) and George Woodward's Eccentric Excursions: Or, Literary \& Pictorial Sketches of Countenance, Character \& Country, in Different Parts of England \& South Wales (1798).

It was not only the Welsh landscape that delighted British domestic tourists. As the critic in the Monthly Review observed of Bingley's account, a journey into Wales could be described 'as a kind of foreign travel which may be performed at home; for without crossing the water, we are introduced to [...] a state of society dissimilar from our own; inhabited by a people altogether distinct from ourselves, speaking a different language' ${ }^{4}$ Sustaining further these contrasts, the reviewer cast Wales as a land inhabited by 'a people interesting as a remnant of the antient [sic] population of the West of Europe, whose very barbarism was qualified by a refined and artificial superstition'. 5 Wales was therefore characterised as a peripheral region that defied the Whiggish ideology of progress and modernity. In emphasising its strange tongue, different people and unfamiliar customs, the reviewer set it 
apart from England in ways which indelibly inscribed upon the 'imagined community' of Britain a series of internal linguistic, historical and cultural boundaries. Thus accounts by English travellers to Wales emphasised divergence and difference in ways which urgently require us to revise Linda Colley's integrationist view of British nationhood forged in the Enlightenment and early Romantic periods. ${ }^{6}$ Rather than offering any narratives of inclusive patriotism, such accounts tended to adopt a more sceptical stance towards such harmonious national visions. Indeed, it is more productive to describe Britain in terms of the internationalised, commercialised, and above all mobile notion of identity used to distinguished itself from its overseas partners - what Benjamin Colbert has termed 'cosmopolitan insularism' - rather than to assert any commonality of feeling within Britain. ${ }^{7}$

Writing of nineteenth-century travellers, Katie Gramich notes that 'the majority of the authors who turn their steps towards Wales are English or European travellers seeking out accessible Otherness' ${ }^{8}$ While by the mid-Victorian period, travel through Wales had certainly been facilitated by extensions to the canal systems to meet the needs of the mining and timber industries, it still represented relatively inaccessible Otherness for late-eighteenth-century travellers from the European Continent, not least those from the German states, whose journeys were generally limited by time and cost to south-east England. Johann Wilhelm von Archenholtz's intimidatingly weighty tomes on the life and culture of the English, England und Italien [England and Italy] (1785), and Gebhard Friedrich August Wendeborn's Der Zustand des Staats, der Religion, der Gelehrsamkeit und der Kunst in Grosbritannien [sic] gegen das Ende des achtzehnten Jahrhunderts [The Condition of the State, Religion, Learning, and Art in Great Britain at the Close of the Eighteenth Century] (1785-88), later followed by his Reise durch einige westlichen und südlichen Provinzen Englands [Journey through Several Western and Southern Provinces of England] (1793), did much to bolster England's reputation in the German states through the 1780s and 1790s.

Despite the German fascination for Celtic primitivism embodied by the figure of Ossian - fuelled by the numerous translations of James Macpherson's writings in the late 1760s and 1770s and culminating in Herder's essay 'Über Oßian und die Lieder alter Völker' ['On Ossian and the Songs of Ancient Peoples'] $(1772 / 73)^{9}$ - such interest remained firmly focused on Scotland. German travel accounts of Wales were few and far between. Translations of English-language accounts of voyages through Wales filled the gap. One of the first to reach a German-speaking audience was Samuel Jackson Pratt's immensely popular account, the Gleanings through Wales, Holland and Westphalia. In its fifth English edition by 1800, the Welsh section of this work was published as the Aehrenlese auf einer Reise durch 
Wallis in the second volume of the travelogue collection Kleinere Länder- und Reisebeschreibungen [Shorter Descriptions of Countries and Journeys] which appeared with the Leipzig bookseller Lincke in $1798 .{ }^{10}$ Declared by the critic in the Allgemeine LiteraturZeitung [General Literary Gazette] to be a good translation of the original, Pratt's work in the German edition offered its readers an imaginatively engaging account of Welsh people and their customs, judiciously curtailed by its translator to free it of sentimental excesses. ${ }^{11}$

In line with recent developments in cultural geography, I am interested in understanding travel accounts as cultural products which draw on particular representational strategies to construct an image of the foreign and are themselves shaped by particular material contexts and practices. In this context, actor-network theory is also useful in determining the agents involved in such processes and the networks within which they operate, as much as the power relations and processes of dominance or resistance which influence how 'translation', both metaphorical and interlingual, takes place. ${ }^{12}$ Pratt's Aehrenlese auf einer Reise durch Wallis exemplifies the way in which texts pertaining to 'peripheral', 'decentred' cultures often undergo a series of mediations before they reach their target audience. If we consider that the Welsh culture, customs and people whom Pratt described were 'translated' once metaphorically through his interpretation of what he saw for his English readership, and then again interlingually for the German edition, then there are multiple opportunities for such appropriation and exploitation. Recent scholarship has heightened our awareness of the ways in which Wales has been 'colonised, appropriated or exploited - economically, culturally and spiritually' by English writers with English ideologies and agendas, ${ }^{13}$ while those working in transfer studies have shifted their focus away from bilateral explorations of cultural transfer between two communities to exploring trilateral, triangular exchange processes. ${ }^{14}$ In the case of the Englishman Pratt's account of his travel through Wales, mediated in turn to a German audience through its Leipzig translator, we are indeed exploring several layers of cultural transfer that generate a complex, image of Wales that is the product of multifaceted and multicultural mediation. ${ }^{15}$

As I examine the different shifts that the text underwent, I shall also be considering how the Welsh came to be represented differently to an Anglophone and a German-language audience. For as Pierre Bourdieu reminds us, regionalist discourse is a performative discourse which aims to impose as legitimate a new definition of the frontiers and to get people to know and recognize the region that is thus delimited', working according to criteria that either can be considered 'objective', such as ancestry, language or religion, or those considered 'subjective', such as feelings of belonging. ${ }^{16}$ In what follows, I start by looking at 
Pratt's Gleanings in terms of its style, structure and literary allegiances, with the aim of understanding where it located itself on the British literary market and by which narrative means it mediated a picture of the Welsh to an English reader. Then I focus on the changes made to Pratt's text during the process of translation, and its repositioning and presentation within a German framework. I seek to understand these modifications within the context of the practices of textual transfer in the German states in the late eighteenth century and the freedoms or strictures that determined how texts could be restyled in translation. In the final section I consider the extent to which Pratt's original English text and its German translation potentially served quite different purposes for their respective reading publics - a factor which governed how Pratt's more Sternian moments of affective description were treated as the text itself 'travelled' across languages and cultures.

\section{Samuel Jackson Pratt (1749 - 1814) and the Gleanings through Wales, Holland and Westphalia (1795)}

Samuel Jackson Pratt's Gleanings through Wales, Holland and Westphalia was one of his later prose works. Born in 1749 the son of a brewer, he nevertheless received a good education and was ordained in the English church. About 1772, he eloped with a 'pretty boarding school miss' and a year later was to be found gracing the boards of the theatre in Smock Alley, Dublin, under the stage name of Courtney Melmoth: his theatrical career was unsuccessful, he and his wife separated and around 1793 he left for the continent to 'glean ideas for future literary efforts'. ${ }^{17}$ His impressive range, if not quality, of early works included The Tears of Genius, on the Death of Dr. Goldsmith (1774), the novel Emma Corbett, or the Miseries of the Civil War (1780), Landscapes in Verse, Taken in Spring (1785) and Sympathy, a Poem (1788), which was described approvingly by the Gentleman's Magazine as full of 'feeling, energy, and beauty'. ${ }^{18}$ The antiquary and author John Britton was similarly encouraging of Pratt's popular five-volume novel Family Secrets, Literary and Domestic (1797-98) and his Letter to the British Soldiers (1797). ${ }^{19}$ Later poems with clear humanitarian preoccupations included The Triumph of Benevolence (1786), Humanity, or, The Rights of Nature (1788) and Bread, or, The Poor (1801).

While some of Pratt's writing was concerned more generally with human suffering, other pieces demonstrate his clear allegiance to a more patriotic, nationalist agenda. In the prefatory material to the Gleanings through Wales, which was omitted in the German translation, he recalled the sense of security he felt as his feet touched the terra firma of 
England after his stay in France, a land 'softening, gradually, from wildness, ferocity, and tyranny' and in the 'disunited Provinces' of the Netherlands. ${ }^{20}$ But while Wales was clearly a crucial site in the Romantic imagination and essential in Pratt's figuring of Britain, was it simply an extension of Albion? How, for Pratt, did Wales resist or succumb to appropriation and what kinds of cultural allegiances and alignments were at work there? In terms which presage the language of Victorian imperialism, he was swift to describe Wales in the opening pages of his account as 'this little appendage to the crown of England' and the 'most beautiful part of the British Empire (for such I think we may fairly call the principality of the ancient Britons', thus relegating it to a peripheral space primarily of visual and nostalgic interest. ${ }^{21}$ Pratt's vision of Wales therefore indulged in a form of simplistic aestheticisation that veered precisely towards what Murray Pittock has termed Celtic 'kitsch'. ${ }^{2}$ Although Pratt emphasised specific couleur locale, his tourist experience clearly framed Wales within a vision of British identity that undermined any notions of cultural nationalism. Yet the primitivist nostalgia for Wales peddled by Pratt was not at odds with his audience's expectations. The Gleanings through Wales, Holland and Westphalia appeared in three volumes with the well-established firm of Longmans in 1795 and was clearly an account which appealed to a broad readership in Britain. As Stephen M. Colclough notes in his study of the reading habits of the fifteen-year-old Sheffield apprentice, Joseph Hunter, Pratt's travelogue was a work Hunter borrowed because, as he noted in 1798, 'the Reviewers gave it a very good character'. ${ }^{23}$ This is not entirely true of Blackwood's Edinburgh Magazine, which did give the Gleanings a five-page review but also remarked rather casually 'Mr Pratt's notes on Wales are not very important, and may be passed over rapidly'. ${ }^{24}$ The Monthly Magazine was more forthcoming, suggesting that the work was 'very amusing, and will be particularly acceptable to the sentimental reader; had the author, however, confined himself more strictly to facts, the work, if less entertaining, had been more valuable'. ${ }^{25}$

The Gleanings described a journey which we can reasonably assume Pratt had indeed undertaken through these countries: Percy Adams reminds us of just how many travel accounts were being produced by writers who had never set foot in the country they claimed to have visited, and Wales, as Moira Dearnley emphasises, was a region that actively invited fantastical and strange description. ${ }^{26}$ Just over three hundred pages of the first volume of Pratt's account were dedicated to Wales, comprising 21 letters (six of which were omitted in translation) addressed to 'the Honourable Mrs B.'. The journey itself, despite claiming to cover both the northern and southern parts of the principality of Wales, was primarily concerned with North Wales: Machynlleth, Dolgellau, Caer Idris, Barmouth, Aberystwyth, 
Ffestiniog, Welshpool and Powis. It was punctuated with musings about the Welsh bards, the Welsh belief in fairies, and how the Welsh buried their dead. It also dwelt on the life and character of the philanthropist, Mr John Howard, who had published a work on the state of the prisons in England and Wales in 1777. Despite being among the earlier cohorts of travel writers on Wales, Pratt was well aware of the travel accounts that preceded his. As Pratt observed, it was the 'most vivid descriptions of Gilpin, joined to the solid narratives of Pennant' which were what inspired him on his journey. ${ }^{27}$ Thomas Pennant, one of the few Welsh commentators on Wales, and a naturalist by profession (elected a Fellow of the Royal Society in 1767), had given an accurate geographical and historical account of the country in his Tour in Wales (1778-83). William Gilpin's Observations on the River Wye (1789) was just one of a series of works in which Gilpin identified locations which he felt offered that kind of beauty in landscape which is 'agreeable in a picture' and therefore adhered to his categories of the sublime, beautiful and picturesque, which were to influence landscape aesthetics well into the nineteenth century.

But there was one other essential component to Pratt's mode of writing: the influence of Lawrence Sterne. Sterne's Sentimental Journey (1768) marked a watershed in travel writing to the extent that its popularity subsequently authorised subjective, autobiographical modes of writing above seemingly objective ones, it questioned the importance of fact over the evocation of place and people, and it assigned greater human and personal importance to what scientific travellers would have classed as trivial. In the introduction to the Gleanings, Pratt had elaborated on what differentiated his account from those of previous travellers:

the modern Mercuries [...] go at full speed to the grand point of their destination [...] - and scarce give time for the horses to be changed at intermediate stages: [...] At day break the next morning they are off, scarce allowing time for swallowing a comfortless dish of coffee, squabbling with their host for extortion, cursing the country they are under the immediate protection of, and disgracing the manners of their own. This done, they continue their expedition as upon life and death, and often - alas, how much too often! finish their folly, their fortune, and their tour, at the same time: ${ }^{28}$

Pratt's approach was different. Travelling under the maxim of festina lente, he resolved to add a new category to the Sternian taxonomy of travel, namely that of the 'residentiary traveller, making a rest in every country' and not hurrying over his ground 'like those who come to a 
full crop, and whom abundance makes careless' ${ }^{29}$ In so doing he implicitly countered some of the main points of censure which Welsh critics levelled at foreign travellers to Wales, namely that they did not speak Welsh, made 'too transient an acquaintance with the inhabitants' and 'have nothing like a resemblance of the men and manners of Wales'. ${ }^{30}$

The gleanings which Pratt considered important departed from the more factual concerns of travellers such as Pennant. The by now rather standard notions of emotional transport underpinned Pratt's landscape descriptions, which were modelled closely on Gilpin's 'sentimental pictures', as Pratt called them. Round Machynlleth, Pratt noted, we found the "true stile of awful grandeur, stupendous rocks rising above one another in barren sublimity' followed by 'the most lovely vales even your imagination can conceive'. ${ }^{31}$ But in recounting his meeting with local people, Pratt's account broke away from the amorality of the picturesque that showed no obvious concern for the poor who inhabited the rural 'picturesque' scenes. Rather, the picturesque was based on 'the effacement of the political and social', with picturesque habits of viewing constructing human figures as 'aesthetically pleasing objects' which 'translated the political and the social into the decorative'. ${ }^{32}$ In his description of Barmouth peasants, Pratt did not stop merely at stating that in them he found poverty and industry united. Rather, he drew the reader in quite some detail into the scene he had witnessed:

The family consisted of fourteen persons, of which, three were too young to relieve their poverty, though just old enough to smile at, and disregard it the rest were, as I said, busily employed. The father of the family was making nets, the mother of it was shaving one of the innkeepers of the place - of her more anon - the eldest son was weaving ribbons - the eldest daughter weaving cloth - the second son was mending a petticoat, that for variety of patch-work, might triumph over Otway's Hag - the second daughter was attempting to repair [...] father's breeches [...] the third daughter [...] was combing the head of the fourth, who was, with no less industry, knitting a pair of stockings $[\ldots] .{ }^{33}$

Instead of making a bald statement of fact, Pratt recreates as a cameo the activities of this large family inside a Welsh hovel. He animates scenes such as these with humour, often with direct or indirect speech, often also with the anecdotal, to recreate these scenes in the mind's eye and to make his account affectively engaging for the reader. The poor 'speak' to us - not 
of course in the Welsh that neither the English reader nor indeed Pratt, I think, would have understood - but through the language of poverty and suffering allied with fortitude and hospitality. The poverty of craftsmen and artisans in Wales was something that Pratt was keenly aware of: and certainly particularly in the cloth-making areas of Montgomeryshire and Merioneth in the 1790s (when Pratt was touring Wales) it was such as to drive some of them to emigrate. ${ }^{34}$ It also pressed home the point that for him identity was associated more closely with a country's people than with its language, its scenery even or its past.

\section{German Travels: Pratt's Gleanings as the Aehrenlese auf einer Reise durch Wallis}

The Aehrenlese auf einer Reise durch Wallis was sandwiched between accounts in the series which are better categorised as 'scientific' travel writing: the army officer Donald Campbell's Journey over Land to India (1795) and the antiquary James Cavanah Murphy's Travels in Portugal (1795). Pratt's account, by contrast, was short on fact and long on sentiment - an imbalance that caused the following assessment to be made by the translator (who was also its editor) in the preface to the very work he was publishing:

Herr Pratt ist einer der beliebtesten neueren Englischen Schriftsteller, und wird manchen unsrer Leser schon als Dichter bekannt seyn. In dieser Reisebeschreibung scheint er vorzüglich Yorick=Sterne, empfindsamen und launigen Andenkens, zu seinem Muster genommen zu haben, den er aber freilich weder an Originalität der Gedanken, noch an Zartheit der Gefühle, noch an tiefen Blicken ins menschliche Herz erreicht; ${ }^{35}$

[Mr Pratt is one of the most popular among the new English novelists, and will already be known to many of our readers as a poet. In this travel account he principally appears to have taken Yorick $=$ Sterne in a sentimental and witty commemoration as his model, which he does not however achieve in originality of thought, delicacy of feeling or in profound insights into the human heart;]

Indeed as the translator continued in his indictment of the Gleanings, the sentiments described degenerated into little more than gossip and generalisations of no consequence. Hard on the heels of this ruthless diagnosis of the work's failings came an account of the surgery that it had undergone at the hands of the translator. All excrescences had been carefully cut away such that the whole thing had now been reduced to less than half the original. ${ }^{36}$ However, 
despite the radically reductive recasting of Pratt's account for a German audience, the translator did not wish to end on a negative note:

Indeß sind Geschmack und Bildung der Leser verschieden; und wem der Empfindsamkeiten und Reflexionen noch zu viel mit unterlaufen sollten, wird sie hoffentlich den übrigen sehr unterhaltenden Nachrichten von einem so interessanten als wenig bekannten Fleck der Erde, wie Wallis ist, zu Liebe, gern übersehen. ${ }^{37}$

[Meanwhile readers' taste and education differ; and whoever considers that too many sentimental passages and reflections creep in will hopefully overlook them gladly among the other most entertaining accounts of such an interesting and little known part of the world, as Wales is.]

In short, the translator hoped that Pratt's account, for all its prolixity and non-linearity, would offer a lively and engaging insight into the Welsh that would presumably differ from other more drily factual, geographically detailed accounts that might appear elsewhere.

The translator was therefore anything but an 'invisible', deferential figure, keen to present Pratt's account to the German public in exactly the same form as it had originally been put on paper in English. Rather, the editorial powers which the translator accorded himself meant that he could rework the travelogue at will. Such interventions were by no means unusual: as Jennifer Willenberg reminds us, Johann Georg Büschel had no qualms about adding his own footnotes to his translation of Richard Sullivan's Observations Made during a Tour through Parts of England, Scotland, and Wales, in 1778 in a Series of Letters (1780), which appeared as the Bemerkungen auf einer Reise durch verschiedene Theile von England, Schottland, Wales with the Leipzig publishers Breitkopf in $1781 .^{38}$ Similarly Georg Forster, perhaps the most famous translator of travel writing in the German states, was responsible for the publication of Thomas Forrest's Voyage to New Guinea (1779; tr. 1782) and George Keate's Account of the Pelew-Islands (1788; tr. 1789) in German, both of which were heavily annotated and radically reshaped or reduced for their new target audience. ${ }^{39}$

Given the cool reception of Pratt's work by its own translator, it is particularly interesting to explore the process of adoption and yet rejection that shapes the act of cultural transfer here. One might have thought, given the vicious criticism voiced by the editor in the preface, that in the German translation all expressions of sentimentality would have been pared down to an absolute minimum. But in reality Pratt's work was so shot through with the 
language of affect that to have purged it of its sentimentality would have been to destroy the very fabric of which it was woven. Indeed, rather surprisingly - considering the translator's opening disdain - those parts of Pratt's work which were translated were done so with a fidelity to the original that suggested a deliberate concern to retain its highly characteristic style and forms of expression. Even neologisms such as 'emparadised' ('I was enveloped emparadised let me call it rather, in this blissful solitude' he noted of the scenery around Machynlleth) were translated with equal creativity in the German: ' $\mathrm{Zu}$ der Zeit, da ich in dieser seligen Einsamkeit eingeschlossen - ich mögte sagen einparadist war, fühlt' ich mich mehr losgerissen von dem Unrath der Welt'. ${ }^{40}$ Dolgellau, abounding in what Pratt termed 'vegetable beauty', could similarly lay claim to 'vegetabilische Schönheit' in German. ${ }^{41}$

The omissions, when they came, were not a series of minor incisions. Rather they were large-scale deletions which the translator himself felt compelled to reflect upon and justify in two longer parenthetic comments. The first, coming in letter seven, noted after several pages of rumination by Pratt on why travellers should mix with high and low company on their travels:

In diesem empfindsamen Tone plaudert Herr Pratt noch einige Seiten lang fort, und da wir besorgen, daß wir ihn für den größten Theil unsrer Leser bereits mehr als zu lange plaudern ließen, so unterbrechen wir ihn hier $[\ldots] .^{42}$

[Mr Pratt chatters on in this sentimental tone for several more pages, and since we are concerned that we have already allowed him to chatter on for far too long for the majority of our readers, we shall interrupt him here]

These twenty pages of omitted text might seem at first glance inconsequential: they reflected on the non-linearity of Pratt's journey and on his pleasure at encountering those 'amiable' people whom other travellers tended to pass by, either because of their haste or the poverty of the people in question. These pages also dwelt on the 'spreading evil' of luxury, to be encountered in London or Dublin, but not in the Welsh valleys whose inhabitants exuded cheerful contentment at their rural way of life. ${ }^{43}$ Thus they indirectly reinforced Pratt's concern with the common man (and notably the rural poor). This was a lens through which Karl Philipp Moritz (like Pratt, a partly pedestrian traveller) had also observed the English in the Reisen eines Deutschen im England im Jahr 1782 (1783) - and been berated by Georg Forster for failing to spend his time more profitably rubbing shoulders with the great and the 
good. ${ }^{44}$ Moreover, Pratt's remarks explicitly denigrated London - which for many German intellectuals represented the apogee of political, cultural and industrial enlightenment - by describing its gaming houses and places of excess and folly, as well as its rich lords who kept horses not for travel or agriculture but merely for the hunt. Cosmopolitan corruption had had a corrosive effect on rural Wales too: there were, Pratt granted, rustic gaming houses in the very heart of Cambria. But their existence represented nothing more than a degeneration from 'the simplicity of ancient manners, and from the honesty of ancient maxims' that otherwise characterised Welsh society. That precisely these kinds of passage should be omitted suggests that Pratt's criticism of urban luxury coupled with his insistence on focusing on the common man may have sat ill with a middle-class German audience that aspired to precisely such luxuries and which was also more interested in imbibing fact - after all, Wales was more or less unknown territory to them - than sharing Pratt's humanitarian concerns.

Throughout the English text, Pratt had also drawn on quotations from English literature which he had woven into the body of text. The Scottish poet James Thomson's immensely popular poem The Seasons (1730) served Pratt with a quotation from a Christmas scene to describe the harmless merry-making he encountered in Wales: 'The rural gambol, and the rustic mirth; / The simple joke that takes the shepherd's heart'. ${ }^{45}$ And from the oriental scholar and poet Thomas Maurice he borrowed the notion that the traveller had 'The world before him where to choose' ${ }^{46}$ These numerous snippets from English literature were used as a device for mediating the experience of travel through Wales to the educated English reader, 'domesticating' it by appealing to a known literary canon. This device was understandably missing from the Leipzig edition, given that German readers could not have been expected to have such an intimate knowledge of English literature and quotations such as these did not draw on any cultural heritage to which they could relate. But the omission of these snatches of English poetry and prose ultimately had a number of different effects on the presentation of Pratt and his work to a German audience. Most obviously, Pratt's self-styling as a travelling man of letters rather fell by the wayside as his work lost its claim to any great literary pretensions. His German readers were also confronted less directly with the fact that they were reading a translation of an account by a traveller with a very different cultural and political take upon the world.

\section{Sterne and Pratt: Sentimental Journeys}

In reflecting on why Pratt's German translator made such extensive changes to the original, it would be important to remember that translation and innovation went hand in hand in the late 
Enlightenment and early Romantic period. If translation is prompted by and itself energetically promotes cultural exchange, then it plays an essential role in revising, refining and recalibrating those images circulating in one nation about the culture, people and politics of another. Michael Maurer and Peter J. Brenner have both demonstrated in their authoritative studies on German anglophilia and on eighteenth-century travel writing that translated (travel) literature was used to sustain or question a range of values, beliefs and narratives as they crossed cultural and language boundaries, contributing in important ways to the social history of Anglo-German relations, and to the examination of constructions and representations of the self and other. ${ }^{47}$ The way in which translators conceived of their role as cultural mediators also changed in the course of the Enlightenment. As Brunhilde Wehinger reminds us, Voltaire considered it an essential component of 'modernity' that the relationship between translator and author should no longer be one of idolisation and subservience but one of comradeship and equality. ${ }^{48}$ This offered translators new freedoms of which Pratt's German translator eagerly partook as he considered how best to reorient the Gleanings through Wales to emphasise its value as an informed and informative piece of writing. Its highly sentimental mode of presentation lay at odds with what the translator considered to be the expectations of a German audience. Yet as Duncan Large has described in a recent investigation of Sterne in the German-speaking world, Sterne had an immense impact on German literature (both fictional and non-fictional) in the eighteenth century. His Sentimental Journey, translated immediately into German by Johann Joachim Christoph Bode, was an instant success. ${ }^{49}$ It spawned an impressive list of adaptations (and some satires) including Die Wanderungen des Herrn Fränkley [The Peregrinations of Mr Frankley] (1777-79), Empfindsame Reisen durch einen Teil der Niederlande [Sentimental Journeys through a Part of the Netherlands] (177475), Reisen für das Herz, in Frankreich geschrieben von Courtney Melmoth [a translation of Jackson Pratt's pseudonymously published Travels for the Heart: Written in France, by Courtney Melmoth from 1777] (1778), Launige Reisen durch Holland. In Yoricks Manier [Witty Travels through Holland. In the Style of Yorick] (1795), as well as Johann Gottlieb Schummel's Empfindsame Reisen durch Deutschland [Sentimental Travels through Germany] (1771-72) - viciously criticised by Goethe for what he perceived as its excessive sentimentality - Georg Friedrich von Rebmann's Empfindsame Reisen durch Schilda [Sentimental Travels through Schilda] (1793) or Christoph von Hedemann's Empfindsame Reise von Oldenburg nach Bremen [Sentimental Journey from Oldenburg to Bremen] $(1796) .{ }^{50}$ 
Indeed, if we examine the reception of Pratt's Aehrenlese auf einer Reise durch Wallis which were published in the German states, it was precisely the Sternian mode (or what remained of it) that critics emphatically enjoyed. As the reviewer in the Allgemeine LiteraturZeitung noted:

Pratt giebt sich für einen verweilenden Reisenden, doch vermehrt er Yorik's Classification noch mit dem poetischen, literarischen und ährenlesenden und zeigt sich daneben, setzt Rec. hinzu, als einen enthusiastischen Reisenden. [...] So bescheiden er von sich gegen Pennant und Gilpin spricht; so war seine Nachlese doch noch ergiebig genug, und er hat das Verdienst, die Empfindsamkeit des letzten mit dem Scharfblick des ersten gepaart zu haben. ${ }^{51}$

[Pratt casts himself as an entertaining traveller, but he extends Yorick's classification still further to include poetic, literary and discerning ones and, the reviewer wishes to add, presents himself as an enthusiastic traveller. [...] As modestly as he styles himself in comparison with Pennant and Gilpin, so his gleanings were still sufficiently fruitful and his achievement is to have combined the sentimentality of the former with the perspicacity of the latter.]

As the reviewer continued: 'Diesem reitzenden Gemälde, denn das ist es mehr als eine Reisebeschreibung, werden alle empfindsame Leser den Vorzug in diesen Lieferungen zuerkennen.' [All sentimental readers will acknowledge the superiority of this charming picture in these representations, since it is more than just a travel account]. ${ }^{52}$ The presentation of Wales to an eighteenth-century German readership was, then, inseparable from the viewing practices deployed by Pratt: practices which actively positioned the Welsh landscape within the aesthetics of the picturesque and the Welsh people within a narrative framework intended to speak directly to German readers' imagination and their sympathy. The reviewer in Ludwig Schubart's Englische Blätter [English Pages] was similarly enthusiastic about the 'talented' Pratt, whose willingness to observe Welsh life in detail by staying with its inhabitants and taking time to understand their concerns was what singled out his account as superior. He too praised Pratt as an 'ecstatic admirer of nature', whose rich and emotive descriptions of landscape were well balanced against his interest in the customs and traditions of the Welsh. ${ }^{53}$ 
It would be wrong to suggest that Pratt's work appeared in translation in the German states at a time when sentimental travel writing was no longer en vogue. But precisely because the excesses of sentimentality had been so scorned by leading writers of the time, and because the Kleinere Länder- und Reisebeschreibungen was a collection devoted to instructive travel literature, I would suggest that Pratt's German translator was actively engaged in trying to 'reform' public taste. The aim of the Kleinere Länder- und Reisebeschreibungen series had been to acquaint readers who were not necessarily of a scientific persuasion with new areas of the world previously largely undescribed. While the agenda set out in the introduction to the first volume had stressed that 'keine umständliche Beschreybungen' [no cumbersome descriptions] would be adopted in this collection and that they would not be overloaded with scientific or geographical fact, they at the same time wished to offer an antidote to the 'so oft schädliche Romanen-Leserei' [so frequently harmful novel reading] to which women and the uneducated allegedly fell victim. ${ }^{54}$ In cutting some of Pratt's more romantic, semi-fictional passages, his German translator sought to divert readers away from sentimentality and towards self-instruction, thereby emphasising more the didactic than the entertaining qualities of the genre of travel writing.

\section{Conclusions}

This examination of how Pratt's Gleanings through Wales, Holland and Westphalia fared in German translation has demonstrated the extent to which the German armchair traveller was not presented with a direct and 'immediate' image of Welsh life, but rather one constructed at a double remove. While the Aehrenlese auf einer Reise durch Wallis was to some extent a 'colonial' and 'appropriative' picture of Welsh culture, Pratt's account also appealed to the reader through the aesthetics of the picturesque and humanitarian concerns reinforced by narrative techniques that elicited readerly sympathy. His German translator was working to a rather different agenda that was more obviously indebted to Bourdieu's 'objective' categories of regionality such as economic activity, territory and religion. If Wales was indeed a peripheral region of the British Empire to the German armchair traveller, then the Leipzig translator's main concern was to supply basic information on its history, culture and geography, rather than stroll with his readers in its picturesque valleys or ponder the plight of its rural poor. It was precisely this sentimentally charged image of Wales, overlooked in the comprehensive but geographically limited accounts by Archenholtz and Wendeborn, which would have made Pratt's travelogue an entertaining read for a German-speaking audience, yet also a highly problematic narrative. The Gleanings through Wales, Holland and Westphalia in 
German translation not only highlighted the 'unexplored' status of Welsh culture, people and customs in the German states at the close of the eighteenth century: it questioned the very methods by which travel literature constructs its image of the foreign.

\footnotetext{
${ }^{1}$ Monthly Review, 48 (1805), 185-96 (196, reviewer's italicisation).

${ }^{2}$ Daniel Defoe, A Tour Thro' the Whole Island of Great Britain: Divided Into Circuits or Journeys (London: Strahan, 1725), vol. ii, 81.

${ }^{3}$ Jane Zaring, 'The Romantic Face of Wales', Annals of the Association of American Geographers, 67 (1977), 397-418 (403).

${ }^{4}$ Monthly Review, 48, 185 (reviewer's italicisation).

${ }^{5}$ Monthly Review, 48, 185-86.

${ }^{6}$ Linda Colley, Britons: Forging the Nation, 1707-1837 (New Haven/London: Yale University Press, 1992).

${ }^{7}$ Benjamin Colbert, 'Britain through Foreign Eyes: Early Nineteenth-Century Home Tourism in Translation', in Benjamin Colbert, ed., Travel Writing and Tourism in Britain and Ireland (Basingstoke: Palgrave Macmillan,
} 2012), 68-84 (70).

${ }^{8}$ Katie Gramich, 'Every Hill has Its History, Every Region Its Romance': Travellers' Constructions of Wales, 1844-1913', in Benjamin Colbert, ed., Travel Writing and Tourism in Britain and Ireland (Basingstoke: Palgrave Macmillan, 2012), 147-63 (147).

${ }^{9}$ See Erhard Bahr, 'Ossian-Rezeption von Michael Denis bis Goethe: Ein Beitrag zur Geschichte des Primitivismus in Deutschland', Goethe Yearbook 12 (2004), pp. 1-16; Howard Gaskill (ed.), The Reception of Ossian in Europe (London: Thoemmes Continuum, 2004).

${ }^{10}$ The sections of Pratt's account on Holland and Westphalia were also translated, and appeared in 1800 as volumes four and five respectively of the Kleinere Länder- und Reisebeschreibungen series.

${ }^{11}$ Allgemeine Literatur-Zeitung, 243 (1799), cols. 281-82.

${ }^{12}$ See more generally Heidi Scott, 'Cultural Turns', in James S. Duncan, Nuala C. Johnson and Richard H. Schein, eds., A Companion to Cultural Geography (Oxford: Blackwell, 2004), 24-37.

${ }^{13}$ Gerard Carruthers and Alan Rawes, eds., English Romanticism and the Celtic World (Cambridge: Cambridge University Press, 2003), 18-19.

${ }^{14}$ See in particular the introduction to Sandra Pott and Sebastian Neumeister, eds., Triangulärer Transfer. Großbritannien, Frankreich und Deutschland um 1800 (Heidelberg: Winter, 2006).

${ }^{15}$ See Harald Kittel and Armin Paul Frank, eds., Interculturality and the Historical Study of Literary

Translations, Göttinger Beiträge zur internationalen Übersetzungsforschung 4 (Berlin: Schmidt, 1991), vii.

${ }^{16}$ Pierre Bourdieu, 'Identity and Representation: Elements for a Critical Reflection on the Idea of Region', in

John B. Thompson, intro. and ed., Pierre Bourdieu, Language and Symbolic Power, trans. by Gino Raymond and Matthew Adamson (Cambridge: Polity Press, 1992), 220-28 (223, 226, author's emphasis).

${ }^{17}$ Oxford Dictionary of National Biography, http://www.oxforddnb.com/view/printable/22710 (accessed 20.01.2011).

${ }^{18}$ Gentleman's Magazine: and Historical Chronicle, 84 (1814), 398.

${ }^{19}$ John Britton, The Auto-Biography of John Britton (London: n. publ., 1850), 142.

${ }^{20}$ Samuel Jackson Pratt, Gleanings through Wales, Holland and Westphalia, with Views of Peace and War at Home and Abroad. To Which is Added Humanity; or the Rights of Nature. A Poem (London: Longman and Seeley, 1795), 3 vols, I, vii, xxx (Pratt's emphasis).

${ }^{21}$ Pratt, Gleanings, I, 6, 18-19.

${ }^{22}$ Murray Pittock, Celtic Identity and the British Image (Manchester: Manchester University Press, 1999), p. 41.

${ }^{23}$ Stephen M. Colclough, 'Procuring Books and Consuming Texts: The Reading Experience of a Sheffield Apprentice, 1798', Book History, 3 (2000), 21-44 (33).

${ }^{24}$ Blackwood's Edinburgh Magazine, 157 (1895), 121-25 (121).

${ }^{25}$ Monthly Magazine, 2 (1796), 486-7 (486).

${ }^{26}$ Percy G. Adams, Travelers and Travel Liars (Berkeley/Los Angeles, University of California Press, 1962). For a detailed account of (more and less) fantastical travel accounts on Wales, see chapter 3 of Moira Dearnley, Distant Fields: Eighteenth-century Fictions of Wales (Cardiff: University of Wales Press, 2001).

${ }^{27}$ Pratt, Gleanings, I, 21.

${ }^{28}$ Pratt, Gleanings, I, 10 (Pratt's emphasis).

${ }^{29}$ Pratt, Gleanings, I, 12, 8.

${ }^{30}$ Critic Theophilus Jones ('Cymor'), 'Cursory Remarks on Welsh Tours or Travels', Cambrian Register for the Year 1796 (1799), 421-54 (422).

${ }^{31}$ Pratt, Gleanings, I, 25.

${ }^{32}$ Stephen Copley and Peter Garside, The Politics of the Picturesque: Literature, Landscape and Aesthetics since 1770 (Cambridge: Cambridge University Press, 1994), 6. 


\footnotetext{
${ }^{33}$ Copley and Garside, The Politics of the Picturesque, 49.

${ }^{34}$ David W. Howell, The Rural Poor in Eighteenth-Century Wales (Cardiff: University of Wales Press, 2000), 65.
}

${ }^{35}$ Aehrenlese auf einer Reise durch Wallis, in Kleinere Länder- und Reisebeschreibungen; aus den Werken vorzüglich ausländischer Reisenden, 7 vols (Leipzig: Lincke, 1798-1800), II, 'Vorerinnerung', iii-v (iv). The translation itself was to be found on pages 8-208 of this second volume of the Kleinere Länder- und Reisebeschreibungen. That the translator and editor were one and the same person is affirmed by the advertisement which the bookseller Salomon Lincke published in the Intelligenzblatt der Neuen Allgemeinen Deutschen Bibliothek, 11 (1800), 91-92 once the series was complete: 'Der Herr Uebersetzer und Herausgeber dieser kleinen Länder- und Reisebeschreibungen hat demnach sein in der Vorrede des 2ten Bandes derselben gethanes Versprechen erfüllt und diese so äußerst interessant anerkannte Reise des Werkes Gleanings trough [sic] Wales Holland und Westphalia etc. by Pratt - nun vollständig geliefert.' (91).

${ }^{36}$ Aehrenlese, iv: 'Alle diese Auswüchse haben wir also weggeschnitten, und glauben darinn so wenig zu viel gethan zu haben, daß wir eher noch zu schonend gewesen zu seyn besorgen, ungeachtet wir das Ganze bis auf weniger als die Hälfte eingeschmolzen haben.'

${ }^{37}$ Aehrenlese, iv-v.

${ }^{38}$ Willenberg, Distribution und Übersetzung englischen Schrifttums, 298.

39 See Alison E. Martin, 'Übersetzung und die Entdeckung der Welt: Georg Forster (1754-794) und die Reiseliteratur', in Harald Kittel, Armin Paul Frank, Norbert Greiner et al, eds., Übersetzung. Translation. Traduction. Ein internationales Handbuch zur Übersetzungsforschung (Berlin/NY: De Gruyter, 2007), 16341641.

${ }^{40}$ Pratt, Gleanings, I, 27; Aehrenlese, 38.

${ }^{41}$ Pratt, Gleanings, I, 29; Aehrenlese, 40.

${ }^{42}$ Pratt, Aehrenlese, 83-84.

${ }^{43}$ Pratt, Gleanings, I, 107. As Hugh Dunthorne rightly remarks, the 'cheerful and incessant labour' which Pratt also observed of a Barmouth fisherman's household was a far cry from the reality of the situation, with riots, food shortages and conscription into the militia being just some of the hardships faced in late eighteenth-century Wales. Hugh Dunthorne, 'Early Romantic Travellers in Wales and the Netherlands', Dutch Crossing 24: 2 (2000), 208-221 (214).

${ }^{44}$ Göttingische Anzeigen von gelehrten Sachen 76 (1784), 765-66.

${ }^{45}$ Pratt, Gleanings, I, 164.

${ }^{46}$ Pratt, Gleanings, I, 80.

${ }^{47}$ Michael Maurer, Anglophilie und Aufklärung in Deutschland (Göttingen: Vandenhoeck \& Ruprecht, 1987); Peter J. Brenner, Der Reisebericht in der deutschen Literatur, Internationales Archiv für Sozialgeschichte der deutschen Literatur (Frankfurt: Suhrkamp, 1990).

${ }^{48}$ Brunhilde Wehinger, 'Auf dem „Marktplatz der Ideen“. Übersetzerinnen im 18. Jahrhundert', in Brunhilde Wehinger and Hilary Brown (eds.), Übersetzungskultur im 18. Jahrhundert: Übersetzerinnen in Deutschland, Frankreich und der Schweiz (Saarbrücken: Wehrhahn, 2008), 9.

${ }^{49}$ Duncan Large, 'Sterne-Bilder': Sterne in the German-Speaking World', in The Reception of Laurence Sterne in Europe, Peter de Voogd and John Neubauer, eds. (London: Continuum, 2004), 68-84.

50 Peter Michelsen, Laurence Sterne und der deutsche Roman des achtzehnten Jahrhunderts (Göttingen: Vandenhoeck und Ruprecht, 1962), 79-101.

${ }^{51}$ Allgemeine Literatur-Zeitung, 339 (23 October 1799), col. 209.

${ }^{52}$ Allgemeine Literatur-Zeitung, 339 (23 October 1799), col. 209.

${ }^{53}$ Ludwig Schubart, ed., Englische Blätter (Erlangen: Walthersche Buchhandlung, 1796), 351-57 (351-52).

${ }^{54}$ Kleinere Länder- und Reisebeschreibungen, I (1798), iv-v. 